Growth Series of

Ostracodes from the

Permian of Texas

GEOLOGICAL SURVEY PROFESSIONAL PAPER 221-G

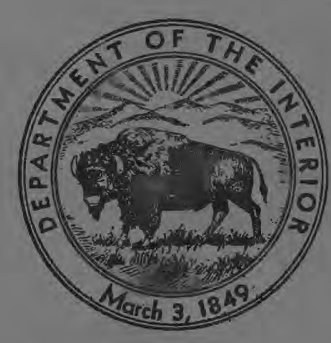




\section{Growth Series of}

Ostracodes from the

\section{Permian of Texas}

By I. G. SOHN

SHORTER CONTRIBUTIONS TO GENERAL GEOLOGY, 1949, PAGES 33-43

GEOLOGICAL SURVEY PROFESIONAL PAPER 221-C

Illustration and description of new genera

and a study based on growth series.

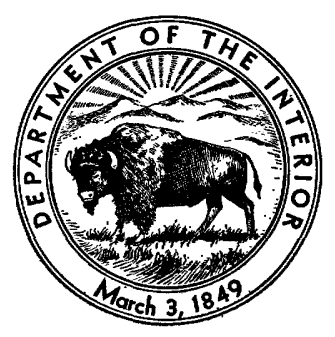

UNITED STATES GOVERNMENT PRINTING OFFICE, WASHINGTON : 1950 


\section{UNITED STATES DEPARTMENT OF THE INTERIOR}

Oscar. L. Chapman, Secretary

\section{GEOLOGICAL SURVEY}

W. E. Wrather, Director

For sale by the Superintendent of Documents, U. S. Government Printing Office Washington 25, D. C. - Price 15 cents (paper cover) 


\section{CONTENTS}

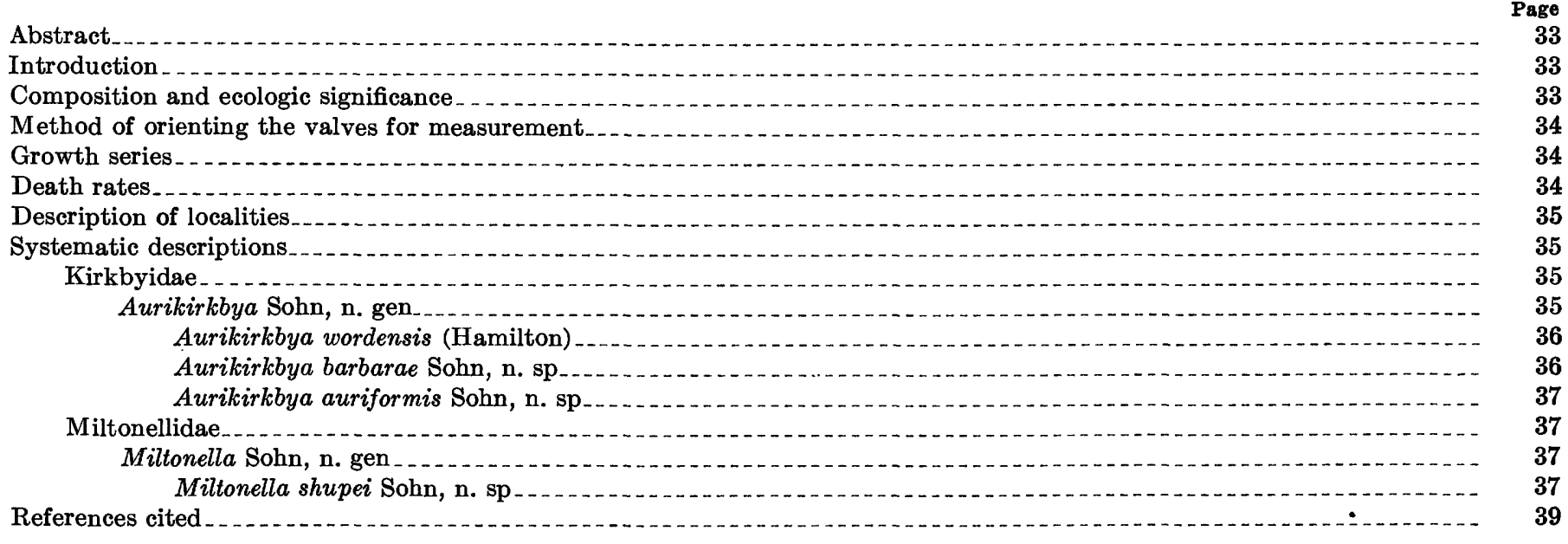

\section{ILLUSTRATIONS}

Plates 7-8. Permian ostracodes from Texas.

$41-43$

FIGURE 2. Frequency distribution of Aurikirlbya wordensis

FrguRe 3. Theoretical percentage of surviving individuals at successive growth stages 



\title{
GROWTH SERIES OF OSTRACODES FROM THE MIDDLE PERMIAN
}

\author{
By I. G. Soнn
}

\begin{abstract}
Two new genera of ostracodes, Aurikirkbya and Miltonella, from the Permian of the Glass Mountains of Texas are described, and a new family, Miltonellidae, is established. The species $A$. wordensis (Hamilton), previously described, is redefined, and two associated new species, $A$. barbarae and $A$. auriformis, are established on the basis of growth series. The new species, Miltonella shupei, is described and illustrated by a series of valves of increasing size.

Measurements of 252 specimens of $A$. wordensis (Hamilton) are recorded. A graph showing the frequency distribution of hinge length of this species is compared with a theoretical graph calculated with death rates of 10,25 , and 50 percent to show the percent of surviving individuals expected at successive growth stages. The fossils under consideration probably do not represent a fraction proportional to the total number of individuals that were available for preservation at the time when the sediments were deposited.
\end{abstract}

\section{INTRODUCTION}

This is the second paper describing ostracodes from the Permian of the Glass Mountains, Texas. The first paper was written by Irving B. Hamilton (1942) who described thirteen new species from the upper part of the Leonard formation or lower part of the Word formation containing silicified fossils-part of the material collected by G. A. Cooper and N. D. Newell (U. S. N. M. loc. $703^{\mathrm{c}}$ ). The fossils described by Hamilton had been leached out of the calcareous matrix with dilute hydrochloric acid. Dr. Cooper's activities at the U. S. National Museum in breaking down the limestone from this locality provided a large amount of material, the study of which disclosed the existence of a larger and more diverse faunule than previously suspected. In addition to the forms described by Hamilton, more than a dozen genera containing from one to three species each were obtained. This paper establishes two new genera, revises one of the previously described species, and adds three new species. These forms are described at the present time because they were cited to illustrate certain points in my paper "Growth stages in fossil ostracodes." (Sohn, 1948, 1950.)

Permission to study this material was given by Dr. G. A. Cooper. Drs. R. S. Bassler, J. B. Knight, and A. R. Loeblich, Jr., of the U. S. National Museum, and Prof. H. N. Coryell, of Columbia University, made type material available for examination.

\section{COMPOSITION AND ECOLOGIC SIGNIFICANCE OF THE FAUNA}

The entire faunule was obtained from the basal portion of an outcrop of dark platy limestone not more than 3 feet thick and about 15 feet in extent. Most of the exposed material was quarried out and removed for leaching. ${ }^{1}$ The contained faunule consists predominantly of sponges that are associated with brachiopods, gastropods, pelecypods, crinoids, foraminifers, bryozoans, and ostracodes. The material that was examined for microfossils is that portion of the undissolved residue which passed through a 10-mesh screen and was retained on a 100-mesh screen. It consists of fragments and very young individuals of the larger fossils, crinoid stems, sponge spicules, ostracodes, foraminifers, and quartz. The frequency of ostracode occurrence is one specimen in about 2,000 grains of other material; the foraminifers are relatively rarer. Because the material examined represents a relatively small though concentrated portion of the sediment, the microfossils are relatively rare in occurrence: the large number of individuals of some of the species is due to the enormous concentration with respect to the original mass of the material.

Silicification preserved the finest ornamentation and spines, and obscured muscle scar structure except kirkbyan pits. The ostracodes occur mostly as dissociated valves, with a very small proportion of complete carapaces. The larger part of the faunule was probably benthonic. Some of the ostracodes (pl. 7, fig. 12) and foraminifers have incrusting forms attached to them; this implies that burial was not rapid. The fact that associated brachiopods and mollusks show evidence of minor reworking by currents or waves indicates that the sea in which the sediments were deposited was probably shallow, possibly not more than 500 feet in depth. It is not possible to determine from the ostracodes whether the biota was endemic or was washed into the place of burial.

Because all the specimens were obtained from one locality, representing a vertical interval of not more than 3 feet of a mass of growing sponges, the entire faunule may be considered as contemporaneous in

\footnotetext{
1 Dr. G. A. Cooper, oral communication.
} 
geologic time. Therefore special attention was paid to growth series which were found in various degrees of completeness for several species.

\section{METHOD OF ORIENTING THE VALVES FOR MEASUREMENT}

To measure ostracode valves for statistical studies or comparison, it is obvious that unless the specimens are oriented in exactly the same manner, the measurements are not significant. In order to obtain uniform data, the length and height on the contact margin as seen on the interior of the valves, and the convexity (width of one valve) in a plane perpendicular to the plane of the contact margins were measured. Measurements along the contact margins of the inside of the ostracode valves have previously been made by Fowler (1909, pp. 221-222) and by Cooper (1946, p. 88, footnote). Cooper did not state the method he used in orienting the valves in order to measure consistently in the same plane; Fowler complained of the difficulty in orienting convex valves, and probably used fine threads of drawn glass to prop up the specimens. Other workers pose the specimens by using wax or modeling clay props.

The valves were attached by the contact margins to a standard glass slide. For convenience of measuring the convexity, the specimen was oriented so that the greatest length was parallel to a long side of the glass slide. A small amount of very dilute gum tragacanth is adequate to attach the valve. To measure length and height the glass slide with the attached specimen was inverted and placed on a cardboard slide (Plummer, 1929 , p. 190) so that the specimen hung down into the well of the slide. By focusing through the glass, the greatest length and height were measured in the same plane.

In order to measure the convexity of the valve, the glass slide was stood up on one edge and the microscope focused on the plane to be measured. To hold the glass slide steady and oriented parallel to the line of sight while the measurement was taken, the slide was backed by a firm support. By taping 20 glass slides with scotch tape a supporting block was built that had a square cross section. The glass slide with the attached specimen was pressed against the supporting block and the microscope was focused upon it.

This method is applicable to dissociated valves only, and usually cannot be used on complete carapaces. It has been used to measure the apertures of biserial foraminifers, and it may be found useful in measuring other microfossils that have at least one flat surface.

\section{GROWTH SERIES}

A growth series of Aurikirkbya wordensis (Hamilton) of more than 250 single valves was measured by using the above method. The specimens ranged in hinge length from $0.8 \mathrm{~mm}$. to $1.8 \mathrm{~mm}$., and it is probable that a number of younger growth stages were not represented.

It was impossible to distinguish between growth stages in this series, because this species apparently does not have the growth stage features of the soft parts reflected on the valves. The appearance of a posterior cardinal spine, which is present in specimens having a greatest length of $1.2 \mathrm{~mm}$. (hinge length $1.1 \mathrm{~mm}$.), may indicate a growth stage at this size.

The graph (fig. 2) shows the frequency distribution of hinge length of $A$. wordensis (Hamilton) based on the recorded measurements. It indicates that it is not possible to distinguish between growth stages of this species on the basis of the length of hinge. Similar graphs constructed for height and for convexity indicate that on those graphs also it is not possible to distinguish between growth stages. Consideration of some of the factors involved indicates that the shape of the graph (fig. 2) is different from the expected curve.

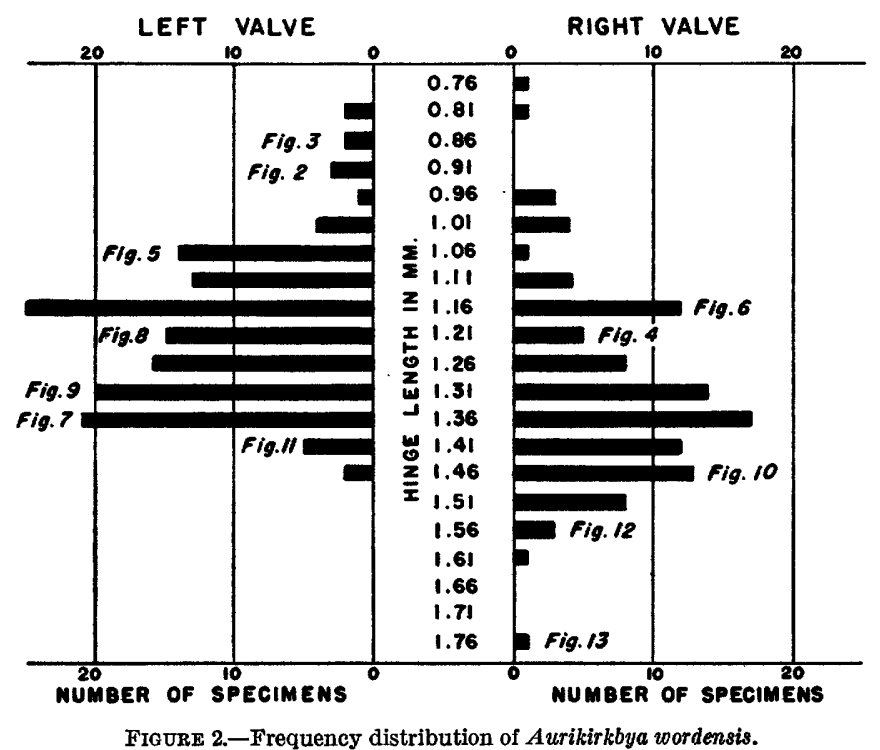

\section{DEATH RATES}

Fowler (1909, p. 309) calculated the death rate of Conchoecia magna Claus as 50 percent between growth stages on the basis of a study of 1171 specimens. Although Fowler's figure may be too high, it indicates that there is a definite decrease in the number of individuals between instars. The youngest instar should be represented by a larger number of individuals than the next instar, which, in turn, should be numerically larger than the following instar, and so on. A graph showing the percentage of individuals surviving at successive growth stages was constructed for death rates of 10,25 , and 50 percent. This graph (fig. 3) shows that the number of individuals in a given population decreases as the ostracodes grow to maturity.

Ostracodes molt between growth stages and the discarded valves are subject to fossilization. Because there are no criteria to distinguish between exuviae 
and dead individuals in fossils, the number of molted valves at each growth stage should be added to the number of dead individuals at each stage. This procedure would increase the number of individuals that are available for preservation at each growth stage.

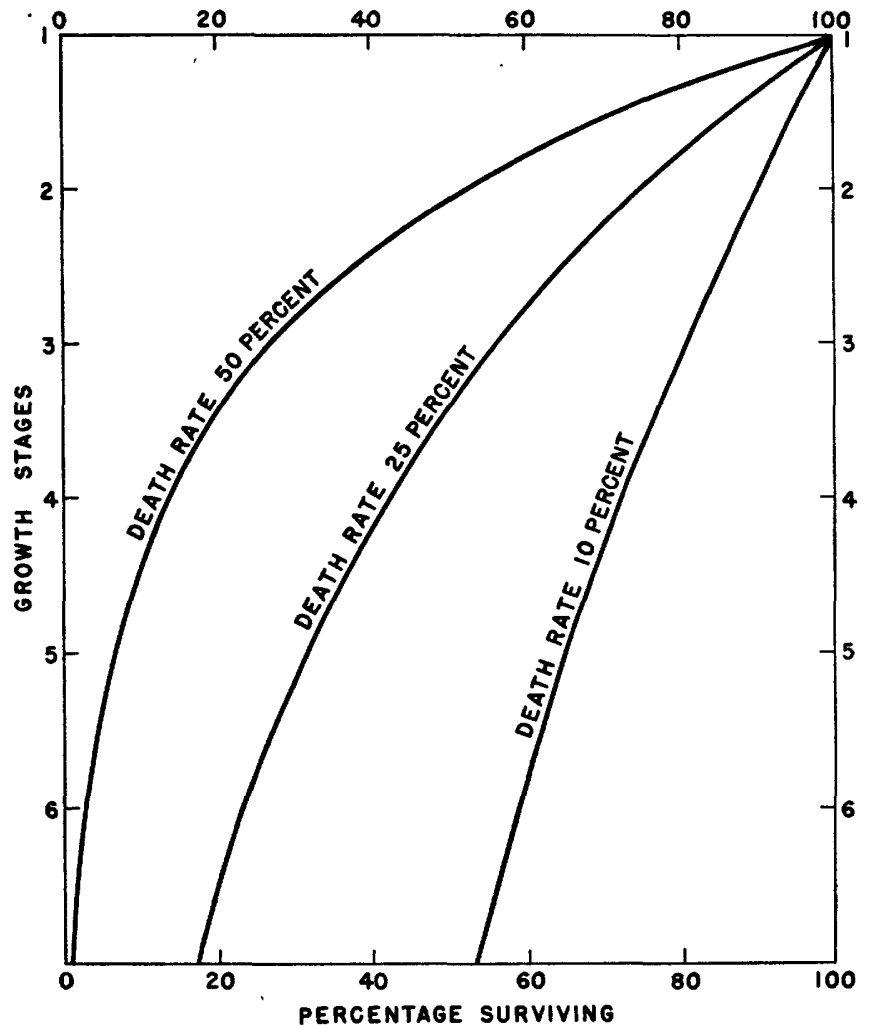

Figure 3.-Theoretical percentage of surviving individuals at successive growth stages.

The graph showing the frequency distribution of size of hinge length of $A$. wordensis (fig. 2), as well as graphs constructed for other species from this locality, and for ostracodes from Tertiary and Silurian formations, do not resemble the theoretical graph (fig. 3). ${ }^{2}$ The reason for this discrepancy may be the fact that the assemblages under consideration do not represent a fraction that is proportional to the total number of individuals that were available for preservation during the time when the sediments were deposited.

In addition to the type locality, the undissolved residue of a limestone of established upper Leonard age was examined for ostracodes (U. S. N. M. loc. 702 ${ }^{\circ}$ ). The ostracodes found are rare in occurrence, poorly preserved, and show beekite ring replacement. Although it is not possible to make specific determination, representatives of both genera described in this paper are present.

\section{DESCRIPTION OF LOCALITIES}

$702^{\circ}$. Upper part of Leonard formation of P. B. King, from $\mathrm{knob}$ on south side of road at elbow just

2 Although figure 2 is not a percentage curve and not comparable to figure 3 , the number of individuals of each valve is so close to 100 as to approximate a percentage curve. west of south branch of Hess Canyon, 4.5 miles by road northeast of Hess gate, 4.2 miles (airline) N. $48^{\circ}$ E. of Hess Ranch, Hess Canyon quadrangle, Brewster County, Tex. Collected by G. A. Cooper, 1945.

$703^{\circ}$. Upper part of Leonard or lower part of Word formation, dark, platy limestone. Crest of slope on north side of road, about $1 / 4$ mile southwest of road fork near old Word Ranch, 17 to 18 miles north northeast of Marathon, Hess Canyon quadrangle, Brewster County, Tex. Sponge bed. Collected by G. A. Cooper and N. E. Newell, 1941, 1945.

\section{SYSTEMATIC DESCRIPTIONS}

Superorder OSTRACODA Latreille

Superfamily BEYRICHIACEA Ulrich and Bassler, 1923

Family KIRKBYIDAE Ulrich and Bassler, 1923

Valves straight-hinged, joined by a ridge or teeth on one valve fitting into corresponding groove or sockets on the other; essentially equal, with the edge of one valve fitting into the slightly rabbeted edge of the other, one valve thus slightly overlapping the other. Surface reticulate, has" several nodes and a subventral pit or muscle spot.

The above description is modified from a description given by Bassler and Kellett (1934, p. 32) because the orientation of some of the genera in this family has been reversed, and also because at least one species, Aurikirkbya wordensis (Hamilton), belonging to this family has been proved to contain individuals that have a reversal of overlap and hingement.

Genus AURIKIRKBYA Sohn, n. gen.

Genotype: A. wordensis (Hamilton), 1942.

This genus is oriented so that the widest end is posterior, thus making the muscle scar area in the anterior half. The hinge consists of a groove on one valve and a corresponding ridge on the other. The ridged valve bears two well-developed terminal teeth, and the opposing or grooved valve has terminal sockets that open to the outside. Overlap consists of the beveled margin of the groovied valve fitting into a rabbeted edge of the opposing or toothed valve. The terminal teeth consist of the thickening of the rabbeted overlapping portion of the valve at the cardinal angles.

Differs from Kirkbya in the presence of two welldefined lobes connected ventrally by a ridge.

Aurikirkbya is placed in Kirkbyidae because the overlap is typical of the family, and because the place of attachment of the adductor muscle, the so-called "kirkbyan pit", is well developed. One species, A. wordensis (Hamilton), is known to exhibit reversal of overlap and hinge structure.

I have examined figures of all the described species of Kirkbya that are listed in Prof. H. N. Coryell's un- 
published index of Ostracoda except $K$. alpina Guembel, 1878, and $K$. schrenkii (Keyserling), 1854, and have been able to eliminate all but the following American species from the new genus:

$K$. canyonensis Harlton, 1929, Univ. Tex. Bull. 2901, p. 153 , pl. 2, figs. $5 \mathrm{a}, \mathrm{b}$.

$K$. kellettae Harlton, 1929, Univ. Tex. Bull. 2901, p. 152, pl. 2, figs. 2a-d (fig. 2e may belong to a different species). $K$. knighti Harlton, 1929, Univ. Tex. Bull. 2901, p. 153, pl. 2, figs. 4a, b.

K. moorei Kellett, 1933, Jour. Paleontology, vol. 7, no. 1, pp. 89-91, pl. 15, fig. 9 (figs. 10 and 11 may belong to a different species).

K. wymani Kellett, 1933, Jour. Paleontology, vol. 7, no. 1, pp. 91, 92, pl. 15, figs. 23-32.

Of the above listed species I would place $K$. canyonensis, K. kellettae and K. wymani in Aurikirkbya. The remaining two species cannot be properly assigned without examination of better material.

Habitat: Marine.

Geologic range: Pennsylvanian and Permian.

Probable ecology: The massive size and flat venter indicate that this genus probably crawled along some surface.

Aurikirkbya wordensis (Hamilton), 1942

P1. 7, figs. 1-13

Kirkbya wordensis Hamilton, 1942 (part), Jour. Paleontology, vol. 16 , no. 6, pp. 713-714, pl. 110, fig. 13.

Hamilton based the description of this species on about a dozen specimens that represent individuals belonging to two distinct species. The species is here redefined and restricted to specimens that have the same features as the holotype.

Carapace subrectangular in lateral view; end margins rounded, posterior margin more sharply rounded; ventral margin varies from straight in adult to somewhat convex in younger individuals. There is a certain amount of individual variation in that some of the smaller specimens have ventral margins that are straighter than those of some of the larger specimens. Greatest length is approximately at midheight.

Posterior lobe or shoulder large, projects above hinge line, is subtriangular in dorsal outline. The posterior slope of this lobe is steep, makes an angle of $60^{\circ}$ or more with the surface of the valve; anterior slope of this lobe is more gentle, making an angle of about $30^{\circ}$ with the surface of the valve. In lateral view this lobe curves down and forward to form a rounded ventral ridge that decreases in size anteriorly, and trends toward the anterior lobe. The ventral ridge varies in height above the lateral surface of the valve; in some specimens it is rounded in cross section and low in height, while in other specimens it is keeled and high. The specimens with a low ventral ridge have the widest part of the valve along the posterior lobe, whereas in those specimens that have a high ventral ridge, the widest part of the valve is in front of the posterior lobe, along the ridge. The anterior lobe is small, projects only slightly above the hinge line, and is separated from the ventral ridge by a shallow sulcus. The anterior border of this lobe curves subparallel to the anterior margin. The muscle-scar pit is well defined, oval in shape, the larger axis of the oval pointing toward the posterior cardinal angle. The pit is located slightly in front of midlength, and just below the ventral ridge in young instars; it grows larger in more mature individuals and impinges on the ventral ridge, causing that ridge to become indented upwards. There is no correlation between the size of the pit and the size of the valve; larger valves may have pits that are smaller than those of smaller valves.

The valve surface below the ventral ridge continues unbroken to the ventral edge of the valve which consists of the inner flange. The lobes are separated from the end margins by two sulci that open dorsally. The inner flange is smooth and thin in younger instars, and broad and reticulated in older instars. This flange masks the ventral margin in lateral view, and is separated from the outer flange by rows of reticulations that form a wall perpendicular to the contact margins. The outer flange is carinate, lies in a plane parallel to the plane of the contact margins, and appears to be very narrow along the ventral margin and to broaden at the end margins; the width of this flange probably varies with individuals and with age. The two flanges converge at the cardinal angles. The inner flange of larger specimens develops a backward-pointing spine that is located below the posterior cardinal angle. Overlap slight; reversal of overlap and hinge structure present, though not common (pl. 7, figs. $7 a, b$ ).

The presence of a posterior cardinal spine in specimens that have a greatest length of $1.2 \mathrm{~mm}$. (hinge length, $1.1 \mathrm{~mm}$.) may indicate a growth stage at this size. The graph showing the frequency distribution of hinge length (fig. 2) indicates that it is not possible to distinguish between growth stages on the basis of size alone.

Type locality: U. S. National Museum locality $703^{\circ}$. Hypotypes: U. S. National Museum nos. 114494114506.

Measurements: See table pp. $38-39 .^{3}$

Aurikirkbya barbarae Sohn, n. sp.

$$
\text { Pl. 7, figs. 14-20 }
$$

Kirkbya wordensis Hamilton, 1942 (part), Jour. Paleontology, vol. 16 , no. 6 , pp. 713-714.

Differs from $A$. wordensis (Hamilton) in the presence of a well-developed ventral ridge below the kirkbyan pit, in the shape of the posterior lobe, in an elongate anterior lobe, in a very narrow outer flange, and in the absence of a posterior cardinal spine in larger specimens.

3 Plate 7, figure 1, is not included in the table because it is of a broken specimen. Its measurements, made on a photograph, are: height, $0.38 \mathrm{~mm}$; convexity, $0.27 \mathrm{~mm}$ 
The oval muscle-scar pit has the longer axis subparallel to the dorsal margin.

Hamilton (1942) included specimens of this species with Kirkbya wordensis, stating that "The ventral ridge is suppressed in immature molts, gaining prominence with maturity." Growth series of both species indicate that in $A$. barbarae this second ventral ridge is well developed in the smallest instar available (hinge length $0.93 \mathrm{~mm}$.), whereas specimens of $A$. wordensis that are almost twice as large do not have this feature. The fact that immature valves show all the characteristics of this species indicates that $A$. barbarae is probably a valid species and not a sexual dimorph of $A$. wordensis. Sexual maturity and associated secondary characteristics in ostracodes appear either in the adult stage or in one. stage prior to the adult. The range in size of individuals having the diagnostic features of either species is large enough to represent more than two growth stages, and it is therefore assumed that the smaller individuals in each of the two species are immature, and are two or more growth stages removed from the adult.

Type locality: U. S. National Museum locality $703^{\circ}$. Holotype: U. S. National Museum no. 114513.

Paratypes: U. S. National Museum nos. 114507114512.

Measurements (as described in text):

\begin{tabular}{|c|c|c|c|}
\hline & $\begin{array}{l}\text { Hinge } \\
\text { length } \\
\text { (milli- } \\
\text { meters) }\end{array}$ & $\begin{array}{l}\text { Height } \\
\text { (milli- } \\
\text { meters) }\end{array}$ & $\begin{array}{c}\text { Convexity } \\
(\text { milli- } \\
\text { meters })\end{array}$ \\
\hline Holotype, fig. 20 & 2. 07 & 1. 09 & 0. 70 \\
\hline \multicolumn{4}{|l|}{ Paratypes: } \\
\hline fig. 14 & 93 & 47 & .31 \\
\hline fig. 15 & .98 & .47 & .33 \\
\hline fig. $16 \ldots$ & 1. 13 & .56 & .37 \\
\hline fig. 17 & 1. 33 & .64 & .44 \\
\hline fig. 18 & 1. 47 & .69 & .49 \\
\hline fig. 19 & 1. 62 & .78 & .60 \\
\hline
\end{tabular}

This species is named in honor of Miss Barbara Sheffer of Brooklyn College, New York, who suggested the auriform appearance of the genus.

Aurikirkbya auriformis Sohn, n. sp.

$$
\text { Pl. 7, Figs. 21, } 22
$$

Differs from the previously described species in the presence of a well-defined anterior ventral note, in shape of posterior lobe, in absence of posterior spine, and in lateral outline.

This species has features in common with both species previously described; it is, however, quite distinctive and easily differentiated from the other two. It differs from $A$. wymani (Kellett) in shape of posterior lobe.

Type locality: U. S. National Museum locality $703^{\mathrm{c}}$. Holotype: U. S. National Museum no. 114514. Paratypes: U. S. National Museum no. 114515. Measurements (as described in text):

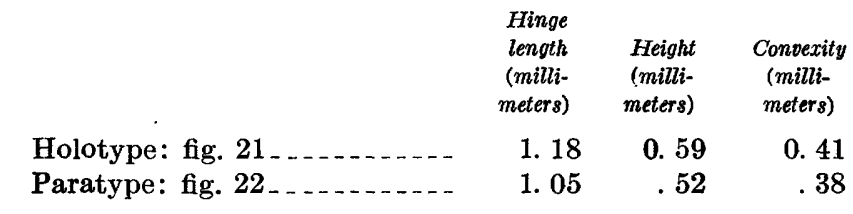

Family MILTONELLIDAE Sohn, n. fam

Straight backed, convex ostracodes with a narrow, shallow groove that extends backward from the anterior cardinal angle and curves around and below the center of the valve subconcentric with the free margins.

Genus MILTONELLA Sohn, n. gen.

Genotype: $M$. shupei Sohn, n. sp.

Miltonellidae in which the left valve overlaps the right along the free margins, and the right valve overlaps the left along the hinge line. The free margins of the left valve are rabbeted to receive the beveled edge of the right valve. Hinge consists of a groove in the right valve and a corresponding flange in the left. The flange is a continuation of the valve surface. The groove is composed of two elements: a dorsal part that is a continuation of the valve surface, and a lower or ventral part that consists of an extension of the beveled edge of the free margins.

The only other ostracode genus known to me that has a similar groove is the Ordovician genus Conchoprimitia Oepik (1935, pp. 4-5) (Primitiidae). Miltonella differs from Conchoprimitia in lateral outline, hingement, and position of the groove.

Habitat: Marine.

Geologic range: Upper part of Leonard and possibly lower part of Word.

Probable ecology: The massive size of the valves indicate that members of this genus probably crawled along some surface.

This genus is named in honor of Dr. Charles Milton, U. S. Geological Survey.

\section{Miltonella shupei Sohn, n. sp.}

Pl. 8, figs. $23-39$

Carapace large, massive, subelliptical in lateral view. Dorsal margin straight. End margins curved, anterior margin larger. The posterior margin has a slight break in its curve located in the dorsal third of the valve height. Ventral margin straight to slightly concave, the degree of concavity varying with individuals. Valves asymmetrical in outline owing to hingement and overlap. Greatest height near the anterior cardinal angle. This angle is located nearer to the front in the left valve than in the right. Greatest length at about mid height. The surface of each valve is broken by a shallow sulcus located at about midlength. This sulcus extends from the dorsal margin and terminates in a subcentral shallow pit. The narrow groove curves below the subcentral pit and terminates at the break in the arc of the posterior margin. The 
groove, the upper part of the posterior margin, and the dorsal margin form an almost perfect ellipse. The free margins are bordered by a row of fine short spines and a very narrow groove located directly above the spines (pl. 8, figs. $39 d, e$ ). Surface of the valves apparently granulose. The preservation of this feature varies with individuals. Dorsal outline subelliptical, greatest width in the posterior quarter, the sides are indented where the central sulcus breaks the con- vexity of the valves; anterior end slightly narrower than posterior.

A growth series of this species consists of individuals that range in greatest length from $0.66 \mathrm{~mm}$. to $2.50 \mathrm{~mm}$. This excludes an undetermined number of younger growth stages that are not represented in the series. It is not possible to distinguish between successive instars on the basis of size. In younger individuals the difference in size between the end margins is not so pronounced as in older specimens. The anterior cardinal angle becomes more distinctly angled with age, causing younger individuals to be nearly more elliptical in lateral outline than more mature individuals. Individuals of this species exhibit considerable variation in outline. All these variants were placed within one species because there are intermediate forms between the extreme variants.
Type locality: U. S. National Museum locality $703^{\circ}$. Holotype: U. S. National Museum no. 114516.

Paratypes: U. S. National Museum nos. 114517114532.

Measurements (as described in text):

\begin{tabular}{|c|c|c|c|c|}
\hline & & $\begin{array}{l}\text { Greatest } \\
\text { length } \\
\text { (milli- } \\
\text { meters) }\end{array}$ & $\begin{array}{l}\text { Height } \\
\text { (milli- } \\
\text { meters) }\end{array}$ & $\begin{array}{c}\text { Convexity } \\
\text { (milli- } \\
\text { meters) }\end{array}$ \\
\hline Holotype & fig. 39 & 1.95 & 1.35 & $\ldots$ \\
\hline \multirow[t]{16}{*}{ Paratypes } & fig. $23 \ldots$ & .67 & .48 & 0.14 \\
\hline & fig. $24 \ldots$ & .65 & .46 & .18 \\
\hline & fig. $25 \ldots$ & .96 & .62 & .26 \\
\hline & fig. 26 & .98 & .65 & .24 \\
\hline & fig. 27 & 1. 35 & .89 & .37 \\
\hline & fig. 28 & 1. 38 & $.95^{\circ}$ & .32 \\
\hline & fig. 29 & 1. 68 & 1.16 & .42 \\
\hline & fig. $30 \ldots$ & 1. 76 & 1. 16 & .42 \\
\hline & fig. $31 \ldots \ldots$ & 1.99 & 1. 31 & .45 \\
\hline & fig. $32 \ldots$ & 1.90 & 1. 24 & .48 \\
\hline & fig. 33 & 2. 16 & 1. 47 & .59 \\
\hline & fig. 34 & 2. 09 & 1. 33 & .51 \\
\hline & fig. $35 \ldots$ & 2. 35 & 1. 57 & .64 \\
\hline & fig. $36 \ldots \ldots$ & 2. 38 & 1. 54 & .67 \\
\hline & fig. $37 \ldots$ & 2. 50 & 1. 71 & .64 \\
\hline & fig. 38 & 2.52 & 1.85 & .66 \\
\hline
\end{tabular}

This species is named in honor of Mr. N. W. Shupe, U. S. Geological Survey, who made the photographs for the plates of this report.

Measurements of Aurikirkbya wordensis (Hamilton)

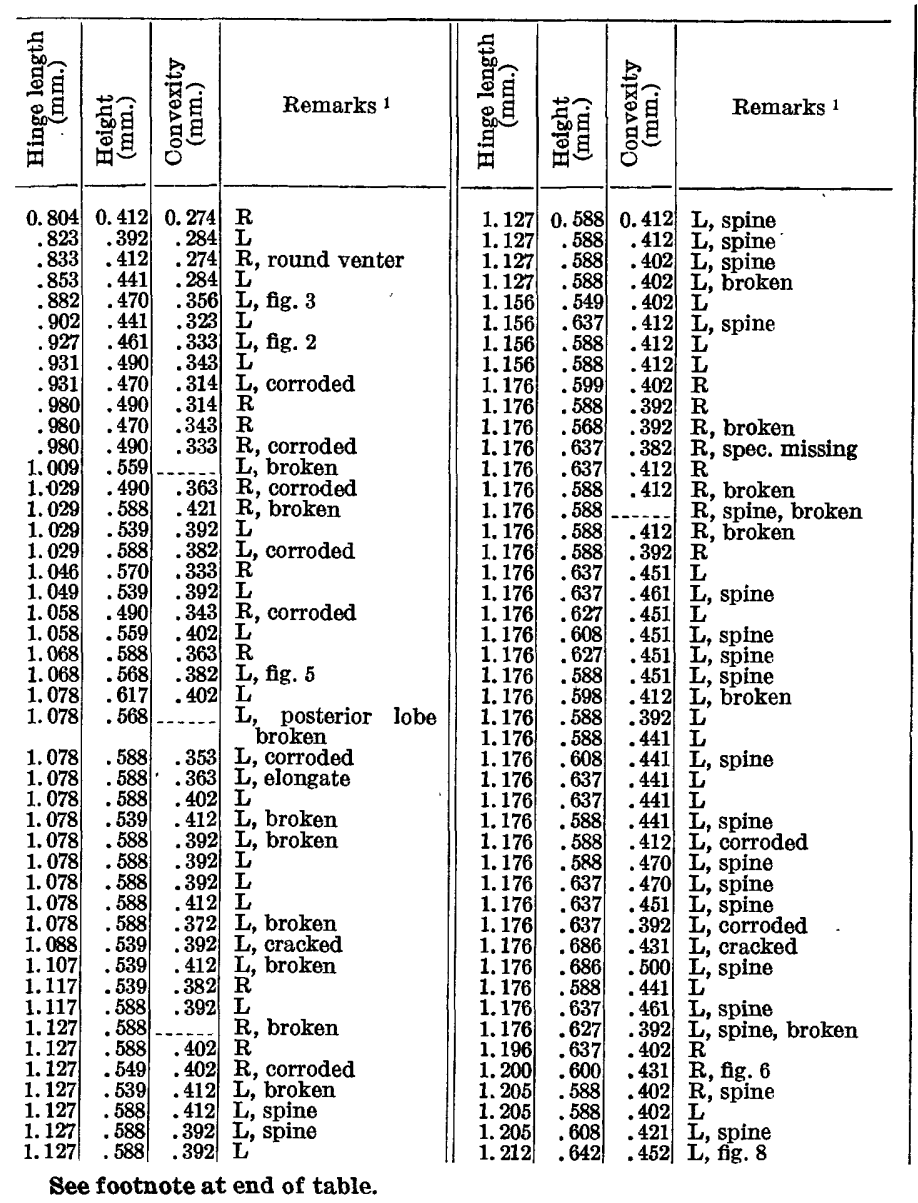

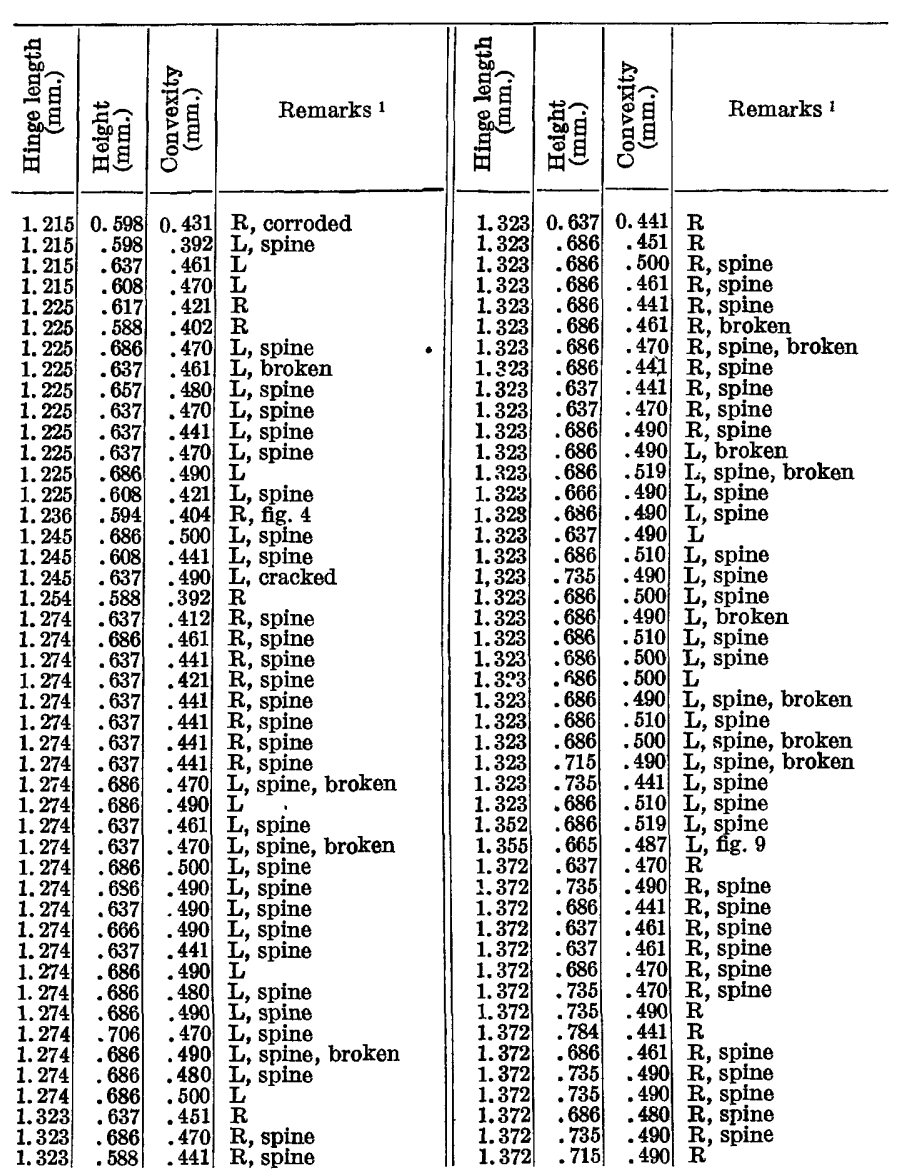




\begin{tabular}{|c|c|c|c|c|c|c|c|}
\hline 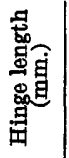 & 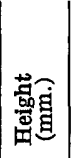 & 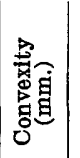 & Remarks & 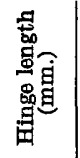 & 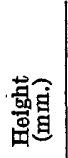 & 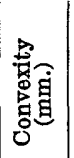 & Remarks ${ }^{1}$ \\
\hline $\begin{array}{l}1.372 \\
1.372 \\
1.372 \\
1.372 \\
1.372 \\
1.372 \\
1.372 \\
1.372 \\
1.372 \\
1.372 \\
1.372 \\
1.372 \\
1.372 \\
1.372 \\
1.372 \\
1.372 \\
1.372 \\
1.372 \\
1.372 \\
1.372 \\
1.392 \\
1.401 \\
1.401 \\
1.421 \\
1.421 \\
1.421 \\
1.421 \\
1.421 \\
1.421 \\
1.422 \\
1.421\end{array}$ & \begin{tabular}{|}
0.735 \\
.686 \\
.735 \\
.735 \\
.686 \\
.735 \\
.735 \\
.735 \\
.735 \\
.775 \\
.686 \\
.686 \\
.686 \\
.686 \\
.764 \\
.735 \\
.735 \\
.735 \\
.784 \\
.786 \\
.685 \\
.686 \\
.686 \\
.686 \\
.686 \\
.735 \\
.735 \\
.706
\end{tabular} & \begin{tabular}{|l|}
0.500 \\
.461 \\
.519 \\
.539 \\
.490 \\
.500 \\
.519 \\
.549 \\
.510 \\
.549 \\
.519 \\
.539 \\
.539 \\
.539 \\
.500 \\
.510 \\
.490 \\
.510 \\
.549 \\
$.48+$ \\
.519 \\
.510 \\
.480 \\
.490 \\
.490 \\
.490 \\
.510 \\
.500 \\
.519 \\
.500 \\
.490 \\
.529 \\
.470 \\
.500
\end{tabular} & $\begin{array}{l}\text { R, broken } \\
\text { L, fig. } \\
\text { L, corroded } \\
\text { L, spine } \\
\text { L, spine } \\
\text { L, spine } \\
\text { L, spine } \\
\text { L, spine } \\
\text { L, broken } \\
\text { L, spine } \\
\text { L, spine } \\
\text { L, spine } \\
\text { L, spine } \\
\text { L, broken } \\
\text { L, corroded } \\
\text { L, spine } \\
\text { L, spine } \\
\text { L, broken } \\
\text { L, spine, broken } \\
\text { L, spine } \\
\text { L, spine } \\
\text { R, spine } \\
\text { R, spine } \\
\text { R, corroded } \\
\text { R, spine } \\
\text { R, spine } \\
\text { R, spine, broken } \\
\text { R, spin } \\
\text { R, spine } \\
\text { R, spine, broken, } \\
\text { corroded } \\
\text { R, spine } \\
\text { R }\end{array}$ & $\begin{array}{l}1.421 \\
1.421 \\
1.421 \\
1.431 \\
1.450 \\
1.450 \\
1.470 \\
1.470 \\
1.470 \\
1.470 \\
1.470 \\
1.470 \\
1.470 \\
1.470 \\
1.470 \\
1.470 \\
1.473 \\
1.499 \\
1.519 \\
1.519 \\
1.519 \\
1.519 \\
1.519 \\
1.519 \\
1.519 \\
1.568 \\
1.568 \\
1.568 \\
1.617 \\
1.764\end{array}$ & $\begin{array}{l}0.735 \\
.755 \\
.735 \\
.735 \\
.735 \\
.735 \\
.735 \\
.735 \\
.735 \\
.735 \\
.735 \\
.735 \\
.735 \\
.735 \\
.735 \\
.735 \\
.784 \\
.735 \\
.733 \\
.735 \\
.784 \\
.735 \\
.735 \\
.784 \\
.784 \\
.784 \\
.784 \\
.765 \\
.784 \\
.784 \\
.882\end{array}$ & $\begin{array}{r}0.549 \\
.539 \\
.568 \\
.510 \\
.559 \\
.560 \\
.500 \\
.490 \\
.490 \\
.470 \\
.500 \\
.510 \\
.490 \\
.510 \\
.519 \\
.519 \\
.500 \\
.461 \\
.568 \\
.500 \\
.578 \\
.529 \\
.519 \\
.519 \\
.510 \\
.539 \\
.539 \\
.568 \\
.559 \\
.490 \\
.570 \\
.568 \\
.539 \\
.559 \\
.637\end{array}$ & 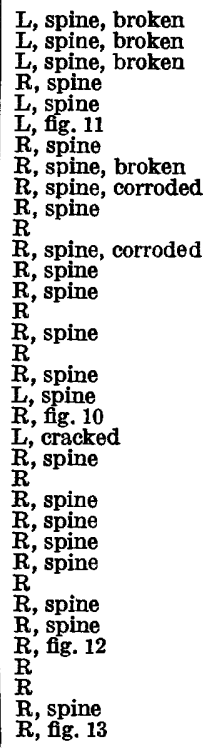 \\
\hline
\end{tabular}

1 L, left valve; R, right valve.

\section{REFERENCES CITED}

Bassler, R. S., and Kellet, Betty, 1934, Bibliographic index of Paleozoic Ostracoda: Geol. Soc. America, Special Paper 1, $500 \mathrm{pp}$.

Cooper, C. L., 1946, Pennsylvanian ostracodes of Illinois: Illinois Geol. Survey Bull. 70, 177 pp.

Fowler, G. M., 1909, Biscayan plankton collected during a cruise of H. M. S. Research, 1900: Linnean Soc. London, Trans., Zool., 2d ser., vol. 10, pt. 9, pp. 219-338.

Hamilton, I. B., 1942, Ostracodes from the upper Permian of Texas: Jour. Paleontology, vol. 16, no. 6, pp. 712-718, pl. 110.

Sohn, I. G., 1948, Growth stages in fossil ostracodes (abstract): Geol. Soc. America Bull., vol. 59, p. 1353.

- 1950, Growth stages in fossil ostracodes: Am. Jour. Sci., vol. 248 (in press).

Oepik, Armin, 1935, Ostracoda from the lower Ordovician Megalaspis-limestone of Estonia and Russia: Univ. Tartu, Pubs. of the Geol. Inst., no. 44, 13 pp.

Plummer, H. J., 1929, Photographic slide mount for micro-fossils: Jour. Paleontology, vol. 3, pp. 189-195. 


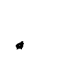


PLATES 7-8 


\section{PLATE 7}

|All figures approximately $\times 18$. In all cases, $a$ is lateral view from the outside, $b$ is lateral view from the inside, $c$ is ventral view, $d$ is dorsal view, and $e$ is posterior view]

FiguRES 1-13. Aurikirkbya wordensis (Hamilton). 1, 4, 6, 10, 12, 13, right valves; 2, 3, 5, 7, 8, 9, 11, left valves; 7a, b, left valve exhibiting reversal of overlap and hingement-compare with figs. 8 and 12 . The tubelike organism on figs. $12 a, d$ is probably the foraminifer Tolypammina. Hypotypes, U. S. National Museum nos. 114494-114506.

14-20. Aurikirkbya barbarae Sohn, n. sp. 15, 16, 17, 18, 20, right valves; 14,19 , left valves. The tubelike void along the ventral margin of fig. $20 \mathrm{~b}$ is due to silicification. Holotype, fig. 20, U. S. National Museum no. 114513. Paratypes, figs. 14-19, U. S. National Museum nos. 114507-114512.

21-22. Aurikirkbya auriformis Sohn, n. sp. 21, holotype, right valve, U. S. National Museum no. 114514; 22, paratype, left valve, U. S. National Museum no. 114515. 


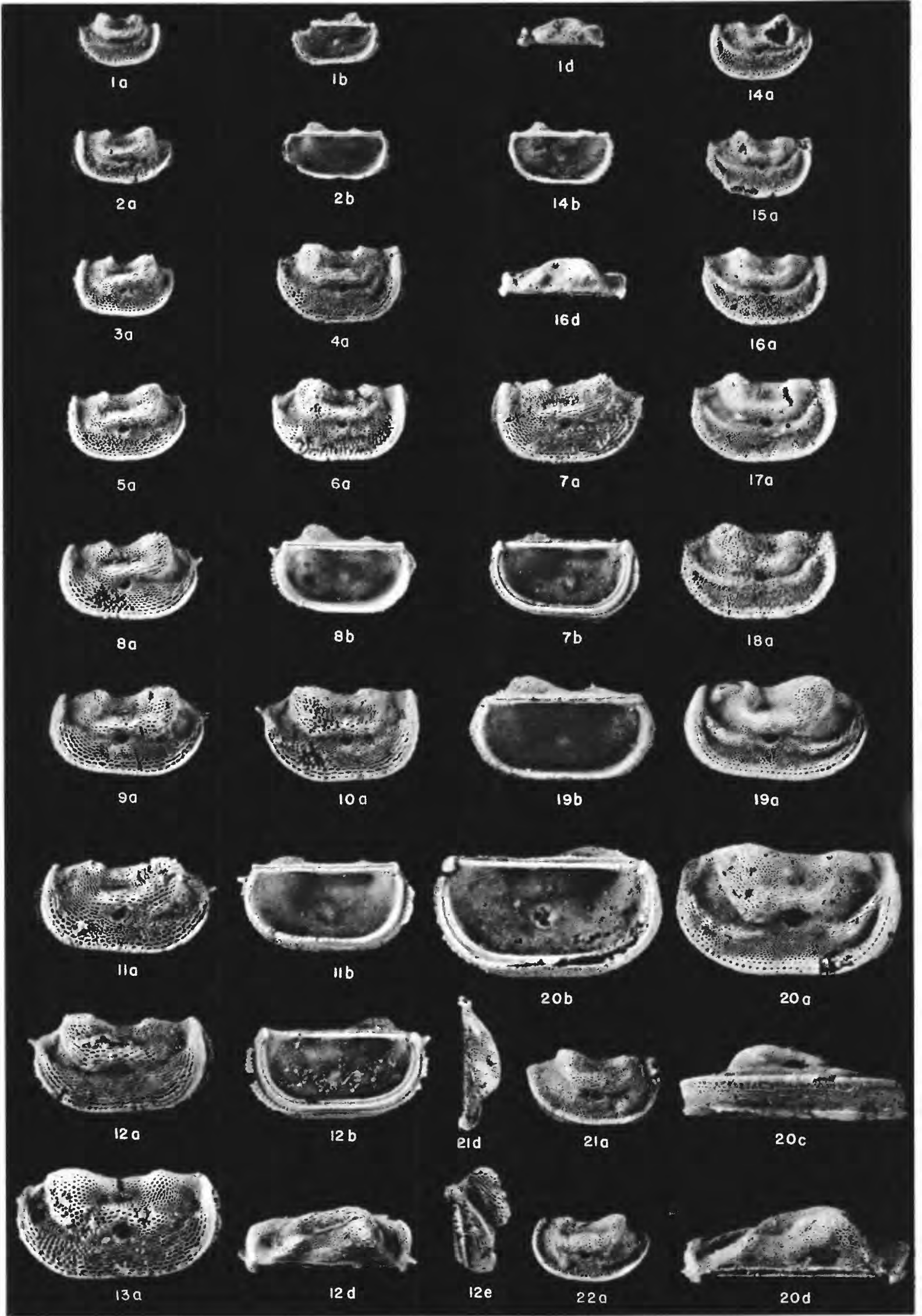




\section{PLATE 8}

[All figures approximatcly $\times 12$ ]

Fig URes 23-39. Miltonella shupei Sohn, n, gen., n. sp. Odd numbers left valves, even numbers right valves; $a$, lateral view from the outside; $b$, lateral view from the inside; $d$, dorsal view; $e$, posterior view. 39 , Holotype, U. S. National. Museum no. 114516. 23-38, Paratypes, U. S. National Museum nos. 114517-114532. 


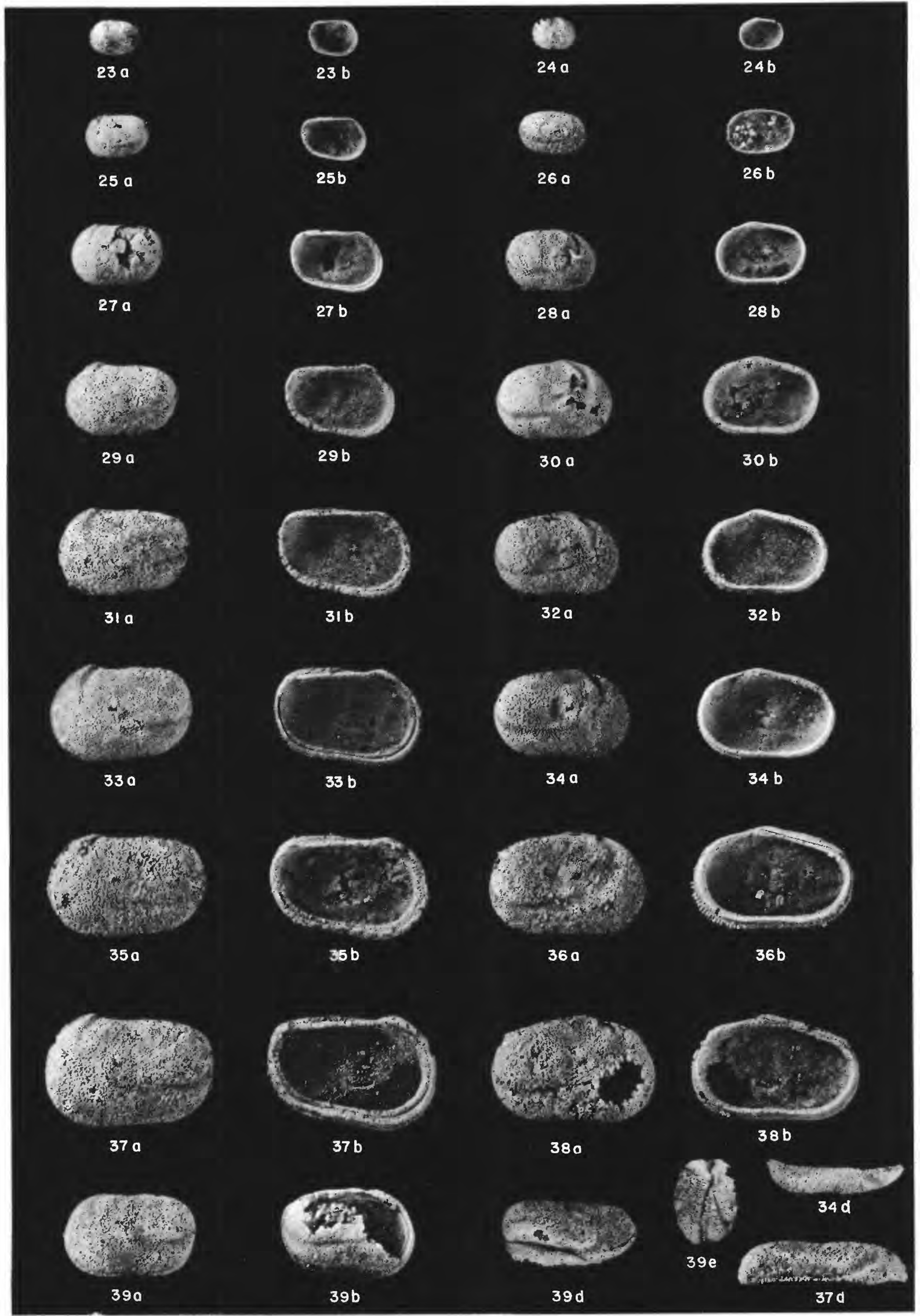


